\title{
Promoting Students' intent of APT by online college English courses
}

\author{
Lanfen $\mathrm{Ji}^{1, \mathrm{a}}$, Dianjun $\mathrm{Lu}^{2, \mathrm{~b}}$ \\ ${ }^{1}$ Foreign Language Department of QinghaiNormalUniversity, Xining 810008, China \\ ${ }^{2}$ Department of Mathematics of Qinghai Normal University, Xining 810008, China

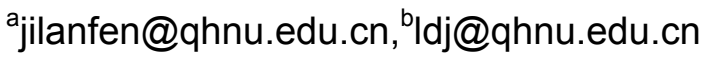

Keywords: online college English courses; intent of APT; blended learning

\begin{abstract}
The purpose of this paper is to investigate students' intent of APT(Active Participation in Teaching)by online college English courses offered at Qinghai Normal University. The survey is conducted among200 non-English majors followed a semester of college English lessons integrated online courses. To examine the students' intent of APT in the course and the new learning environment at the end of the teaching period, a questionnaire was administered and interviews were conducted. The findings indicate that despite the difficulties they faced, the students were satisfied overall with the application of online college English courses and promoted the intent of APT.
\end{abstract}

\section{Introduction}

Since the developments in online courses captured the interest of many people from different fields, computers have become one of the indispensable elements of our modern lives. Providing new opportunities for delivering information, and easing communication and resource sharing, Online college English courses are also challenging educational institutions to integrate Online college English courses into their curricula and utilize them in some ways. As a result, many researchers have directed their attention to these new pedagogical tools and started to investigate their utility in relation to what face-to-face courses offer from the perspectives of students, teachers and educational institutions. In order to have a better understanding of students' intent of APT of college English lessons, it is essential to learn about the concepts and ideas about students participation.

In Erickson's view[1], student participation is an active course experience. Active participation is the premise and basis of creative study, which is an ability of independent study for the students.Students in the completion of experience can be divided into two parts at least: the first is the social contact, the second is the teaching material.The former includes social connections such as the student and teacher, student and student.The latter includes psychological contact such as students and teaching materials, classroom teaching combines students and teachers together. Aspects such as teachers and students in choosing materials, the purpose of immediate and long-term even more general cultural background, will influence the interaction of the students and teachers, it also will affect the students' and teachers' subjective experience respectively. Erickson believes that the purpose of course sometimes cannot cause the resonance of the students, the students' behavior might or might not differ with the purpose of authority with the outside world.Students sometimes feel irrelevant and boring about the assigned task.Because the student is not willing to learn or it's hard to grasp specified content, student's learning would not happen. Erickson believes that there exists both the practice of building knowledge and the practice of resisting knowledge in the process of school education.

In fact, since the 1990s studies about student participation involve different aspects like the behavior participation, emotional participation and cognitive participation. Researchers on the study of the students to participate in the concept, according to their own research angle, consider students participation, emotional participation and cognitive participation. Participation in the teaching strictly emphasize the students' inner subjectivity according to the student's actual needs and desires.Knowledge is not embedded in students. Knowledge is students' positive internalization. It 
makes students' learning attitude and behavior head for positive teaching behavior.Student participation in teaching fully display student's dominant role. Student participation in teaching is the student's high quality learning under the condition of online courses. The characteristics are as follows:(1) Generativity: Student participation in teaching is no longer a one-way transmission of knowledge, but rather on the basis of interaction with others, to build their own understanding of knowledge (2) Open: Student participation in teaching can admit wider range of teaching content, it can allow a different teaching method, it can accept different evaluation (3) Cooperative: Participatory teaching advocates the cooperative engagement. Participants can speak out their own points of view, they also share the wisdom of others. Through cooperation participation becomes a kind of multidirectional communication and wisdom exchanges.(4)Comprehensiveness: Student participation is a full participation. On the one hand, students participate in every link. On the other hand, the students involve with both body and mind. Students are required to devote themselves to their teaching activities generating emotional resonance.

Active participation have three kinds of manifestation:

(1) in high spirits. Students in this positive emotional state can be seen as a great interest in learning and their high learning enthusiasm.

(2)interaction. To let the students participate in actively, they should be provided a broader communication space for students, so that the students acquire the knowledge and experience in the main dynamic interaction. The multidirectional interaction between students and teachers can both satisfy the students' thirst for knowledge, and to exert students' subjective initiative, and can also improve the level of students' intellectual activities.

(3)Wide participation. After class communication is done amongpartners, in the process, each student has the opportunity to express their opinion. Students must have their own opinions to communicate again, in the process of talk show, the participation of students is one hundred percent.

In the preceding literature it has been proposed that the students intent of APThave some interactions with their motivation and interests towards using and learning to use computers and the Internet, or vice-versa[2,3]. Numerous studies point to a positive correlation between intent ofAPTandlearners' success in both the subject matter learned and the use of communication technologies[4,5]. For instance, Easton and Damodaran [6] asserted that no intent of APT might affect individualmotivation and performance.

Regarding the importance of the Internet and its contribution to language learning environments,similar to C.S. Sagin Simse's research[7], thisstudy presents a research study carried out with university students in Qinghai Normal UniversityParticularly, the study intendsto reveal online college English courses can help promote students intent of APT towards an college English integrated online courses. The data used for the analysis were obtained via a questionnaireadministered to 200 undergraduate students and via a follow-up interview with 75 of the students, randomlyselected.

\section{Methodology}

\section{Participants and the setting}

This study was carried out among non-English majors at Qinghai Normal University. The 200 students who took partin this study were asked to take college English. The course aimed at making students competent in various language skills, such aslistening, speaking, reading and writing words and passages accurately and efficiently. Regular college English lessons are given through face-to-face instructionin the classrooms and the Internet environment is not used specifically for teaching purposes but for makingannouncements about assignments, readings, grading, etc. Thus, the participants, in this study havesome experience of an online course, but nearly all of them were familiar with the Internet facilities.

\section{The procedure}

So as to explore students'intent of APTbyusing online college English courses. The concept ofblended learning was adopted and the Internet facilities were incorporated with the teaching tools 
of face-tofaceclassrooms. Since the students did not have to be in the same place at the same time,throughout the study students were provided with space and time independence to cover the weekly materials.

Interaction between students and the teacher was enacted via e-mail messages, a discussion group formed onthe Internet, and regular face-to-face class meetings. The course consisted of different lessons and different types ofexercises about them. Each week, the students worked on given exercises and after completing the exercisesthey sent their work to the teacher. There was a time limitation of three days set forfinishing their work. When students' answers were received by the instructor, they were read and then feedbackabout their work was sent to the students via QQ group and typical mistakes were explained on the screen in the face-to-face classrooms.

\section{Results and discussion}

This section presents and discusses the main results obtained via the attitude questionnaire. The section isorganized according to the three main parts of the questionnaire. For statistical analysis the responses were allcoded and analyzed using the Statistical Package for Social Sciences (SPSS) version 10.0 for Windows. Statisticalmethods used included frequency, percentage, mean, and standard deviation. The results in tables arereported with the mean scores (M) and standard deviations (SD) of the responses.

Table 1 presents the results for the items relating to the college English lessonsincorporated online courses in comparison to the face-to-face courses. Forinterpretation, mean scores 80 and above are considered to reflect positive, 60 and around neutral, and50 and below negative.Overall, the attitude of the students towards college English lessons integrated online courses tended to be positive (with the totalmean score 74.71 out of 100 and $\mathrm{SD}=17.77$ ) indicating that the majority of the students accepted the use ofonline college English courses and the Internet for learning, and implying their acceptance of the value and significance of the onlinecourses. Theseresponses showed that most of the students believed that college English lessons integrated online courses offered them the opportunityfor learning individually by providing time flexibility and also confidence to ask questions directly. In spite of these positive features, an important drawback of the course, the fact that they experiencedmany technical and equipment difficulties, was also pointed out by the students.

Table 1 Attitudes towards the online college English courses

\begin{tabular}{lcc}
\hline Statements & M & SD \\
\hline I have a acttive attitude toward the use of online college English courses for & 4.57 & 0.57 \\
learning & 4.54 & 0.56 \\
Online college English courses are more personal than face-to-face courses & 4.50 & 0.73 \\
I have a positive attitude toward the use of the Internet for learning & 0.85 \\
Students in Online college English courses feel more comfortable in asking & 4.37 & \\
questions & 4.30 & 0.85 \\
Online college English courses allow students to learn at their own pace & 4.03 & 0.92 \\
Online courses encourage students to learn more & 3.91 & 0.95 \\
Teachers in online college English courses are more available & 3.82 & 1.14 \\
Online college English courses are more flexible with regard to my time & 3.83 & 0.94 \\
Students in online courses learn more & 3.65 & 1.05 \\
Students in online college English courses are more satisfied & 3.64 & 0.88 \\
Students in online college English courses know their teachers better & 3.67 & 0.81 \\
Students in online college English courses ask more questions & 3.66 & 0.77 \\
Working on student projects in online college English courses is easier & 3.50 & 0.75 \\
Online college English courses are easier & 3.37 & 0.85 \\
Online learning environments are better for learning & 3.35 & 0.93 \\
Students in online college English courses have fewer problems getting help & 3.13 & 1.02 \\
Students in online college English courses communicate with each other more & 3.10 & 1.05 \\
Students in online college English courses know other students better & 2.92 & 1.35 \\
online college English courses have more technical difficulties & &
\end{tabular}


online college English courses have more equipment difficulties

2.85

0.8

Statements in all tables are listed from higher to lower so that the higher the score, the more positive the attitude, and vice-versa. The results in Table 1 also point out that despite the technical and equipment difficulties the studentsfaced, the students developed positive intent of APT by online courses.

The second section of the questionnaire required information about the online learning environment createdfor the purpose of college English. Table 2 reports the responses relating to the students'intent of APT towards the course atmosphere. With the total mean score 43.60 out of 60 $(\mathrm{SD}=12.04)$, thestudents' intent of APT for the second part of the questionnaire can also be interpreted as positive. The data suggest that the college English lessons integrated online courses was found to be encouraging mainly because the studentsthought that this course gave them more time flexibility than face-to-face courses. For instance, the studentsreported that they were allowed to learn at their own pace, unlike face-to-face courses where students have tokeep up with the pace of the teacher. Moreover, they indicated their satisfaction with the course becausethey were provided with an adequate amount of time to complete the tasks and they could self-schedule theirtime.

Table 2Attitudes towards the learning environment

\begin{tabular}{lll}
\hline Statements & M & SD \\
\hline The format of the course encouraged students to learn & 4.10 & 0.84 \\
The teaching techniques and the technology used enhance leaning & 4.06 & 0.69 \\
I was able to learn at my own pace more in this course & 4.00 & 0.87 \\
I participated more in the Online college English courses integrated course & 3.83 & 0.94 \\
I felt comfortable in asking questions in this course & 3.80 & 0.99 \\
Overall, I am satisfied with the learning environment created in this course & 3.80 & 1.12 \\
I am more satisfied with the class discussions in this course & 3.73 & 0.86 \\
I am satisfied with how I was able to schedule my time in this course & 3.63 & 0.88 \\
Working on student projects was easier in this course & 3.56 & 1.07 \\
I am satisfied with the amount of time required for this course & 3.43 & 1.38 \\
I communicated well with the students in this course & 3.10 & 1.15 \\
I often felt the need for face-to-face communication in this course & 2.56 & 1.25 \\
\hline
\end{tabular}

Another positive aspect revealed about the online learning environment was that the students estimated theirparticipation rate higher in the online college English courses. A very important fact is revealedby the data, thatthe students often felt the need for face-to-face communication in the college English lessons integratedonline course. This result is consistent with the findings of Gal-Ezer and Lupo[8] who pointed that "the Webcannot substitute entirely for face-to-face learning, but it can serve as a reasonable alternative when the latteris unavailable". It is especially reported by Rovai and Jordan[9] that such students, particularly dependent learnersfrequently need direction and reinforcement from a visible professor. However, it should be noted that in this study working individually did not result in student frustration.

The reason for this might be that the subjects of this study were together with their classmates in theirother courses and that most of them were staying together in university dormitories. Thus, the students hadthe chance to see and communicate with each other. In addition, the immediate feedback they received fromthe teacher might have prevented the students from feeling frustration.

The results on the overall satisfaction with the online college English courses integrated course, displayed in Table 3, indicate thatthe majority of the students were satisfied with the manner in which the course was delivered. Overall, theythought that the teaching techniques and the technology used in the online course enhanced their learning. Therefore, more than half of the students stated that they would like to take another online course if it wereoffered. 
Table 3Overall satisfaction with the course

\begin{tabular}{lll}
\hline Statements & M & SD \\
\hline Overall, I am satisfied with the learning that occurred in this course & 4.23 & 0.97 \\
Overall, I am satisfied with how this course was delivered & 4.03 & 0.85 \\
I would recommend this course to my friends & 3.93 & 1.22 \\
I would take another Online college English courses integrated courses if it were & 3.70 & 1.17 \\
offered & & \\
\hline
\end{tabular}

\section{Conclusion}

The students believed that they participated more in the college English lessons integrated online course. The basic reason was that students had difficulty in catching up with the pace of the teacher and with the other students in face-to-face courses. Thus, most of the times, they remained silent in class and did not participate in the activities. Students' personalities such as their being shy or afraid of being ridiculed by the other students because of their mistakes were the other factors that prevented students from participating. However, since all the students answered all the questions and completed all the exercises before sending them to the teacher, this course gave them a chance to work alone and at their own pace.We can see that the intent of APT by online courses were developed despite the difficulties the students experienced. Students managed to accomplish the tasks and liked this blended learning environment.

\section{Acknowledgments}

This research was supported by Science and Technology Innovation Ability Enhancement Planning Project of Qinghai Province(2015-ZJ-724) and by the Ministry of Education Chunhui Program(JWSL[2014]1310). This research wasalso supported by scientific research foundation of QinghaiNormalUniversity.

\section{References}

[1] B. Erickson, A. Allen, and L. Mountain. Telecommunications Promotes Summer Reading and Writing: A Pilot Project Report, Journal of Computing in Childhood Education, 3 (1992), 295-302.

[2] R.Coffin,P. MacIntyre. Motivational influences on computer-related affective states. Computers in Human Behavior, (1999)15(5), 549-569.

[3] P. Houle. Toward understanding student differences in a computer skill course. Journal of Educational Computing Research, (1996)14(1), 25-48.

[4] T.Levine, S. Donitsa Schmidt. Computer use, confidence, attitudes, and knowledge: A causal analysis. Computers in Human Behavior, (1998)14(1), 125-146.

[5] S.Yu, K.Yang. Attitudes toward web-based distance learning among public health nurses in Taiwan: A questionnaire survey. International Journal of Nursing Studies,(2006) 43, 767-774.

[6] K.Easton, L.Damodaran. The needs of the commercial user. In M. J. Coombs \& J. L. Atly (Eds.), Computer skills and the user interface, (1981) 115-139. New York: Academic Press.

[7] C.S. Sagin Simsek, Students'attitudes towards integration of ICTs ina reading course: A case in Turkey, Computers \& Education 51 (2008) 200-211.

[8] Gal-Ezer, J., \& Lupo, D. (2002). Integrating Internet tools into traditional CS distance education: Students' attitudes. Computers \& Education, 38(4), 319-329. 
[9] Rovai, A., \& Jordan, H. (2004). Blended learning and sense of community: A comparative analysis with traditional and fully online graduate courses. International Review of Research in Open and Distance Learning, 5, 2. 